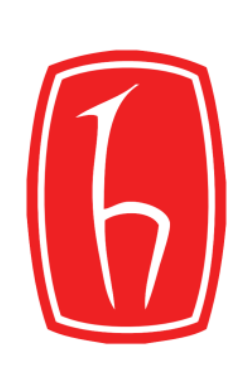

Hacettepe Üniversitesi Edebiyat Fakültesi Dergisi

Hacettepe University Journal of Faculty of Letters

Aralık/December 2020 - 37(2), 321-329

doi:10.32600/huefd.687279

Hakemli Makaleler - Refereed Articles

Geliş Tarihi / Received: 10.02.2020 Kabul Tarihi / Accepted:23.05.2020

\title{
Benlik Saygısı ve Yaşam Memnuniyeti İlişkisi: Ağrı İbrahim Çeçen Üniversitesi Öğrencileri Örneği
}

\author{
The Relationship Between Self-Esteem and Life Satisfaction: Case of the Students of \\ Agri Ibrahim Cecen University
}

Abdurrahim GÜLER*

\section{$\ddot{\mathbf{O} z}$}

Bu çalışmanın amacı Ağrı İbrahim Çeçen Üniversitesi'nde eğitim gören öğrencilerin demografik özellikleri ve benlik saygılarının yaşam memnuniyetine olan katkısını incelemektir. Benlik saygısının öğrencilerin üniversite dönemlerinde kariyer planlamadan kaynaklı olarak yükseldiği öngörülmektedir. Bu nedenle benlik saygısının öğrencilerin yaşam memnuniyetini olumlu yönde etkilediği yapılan çalışmalarla ortaya konulmuştur. Araştırmanın örneklemi ilgili üniversitedeki 136 öğrenciden oluşmaktadır. Araştırmanın verileri yaşam memnuniyet ölçeği, benlik saygısı ölçeği ve demografik özellikleri kapsayan tarama yöntemiyle toplanmıştır. Genel olarak bakıldığında katılımcıların benlik saygısı ve yaşam memnuniyeti puan ortalamaları yüksek çıkmıştır. Buna rağmen demografik özellikler ile yaşam memnuniyeti arasında anlamlı bir ilişki bulunamamıştır. Cinsiyet ve sınıf düzeyi farklılıkları benlik saygısı ve yaşam memnuniyeti üzerinde bir farklılık göstermemiştir. Benlik saygısı ile yaşam memnuniyeti arasında pozitif ve anlamlı bir korelasyon saptanmıştır. Ayrıca çoklu regresyon analizine göre benlik saygısı yaşam memnuniyetinin önemli bir açıklayıcısıdır. Araştırmanın sonucuna göre katılımcıların benlik saygıları yükseldikçe yaşamdan aldıkları doyum da artmaktadır. Ayrıca benlik saygısı demografik özelliklerin etkisi kontrol altına alındıktan sonra yaşam memnuniyetini anlamlı bir şekilde açıklamaktadır.

Anahtar sözcükler: Yaşam memnuniyeti, benlik saygısı, demografik özellikler, Ağrı İbrahim Çeçen Üniversitesi.

\begin{abstract}
The purpose of this study is to investigate the contribution of demographic characteristics and self-esteem on life satisfaction. Self-esteem is predicted to increase during the undergraduate years as a consequence of career planning. Previous research has shown that self-esteem positively affects students' life satisfaction. The sample consisted of 136 students studying at Agri Ibrahim Cecen University. The data were collected using a survey method, which included measures of life satisfaction, self-esteem and potential demographic characteristics. In general, participants reported high scores on both self-esteem and life satisfaction. However, no significant relationship was found between demographic characteristics and life satisfaction. Gender and level of education made no significant contribution to self-esteem and life satisfaction. A positive and significant correlation was found between self-esteem and life satisfaction. Also, according to multiple regression analysis, self-esteem was an important explanatory factor in life satisfaction. Results suggest that, as the participants' self-esteem increases, the satisfaction they receive from life
\end{abstract}

\footnotetext{
* Dr. Öğr. Üyesi, Ağri İbrahim Çeçen Üniversitesi, Fen Edebiyat Fakültesi, Sosyoloji Bölümü, e-posta: aguler@agri.edu.tr, ORCID:0000-0002-0317-8221
} 
increases as well. Self-esteem was found to be significantly predicting life satisfaction after controlling for the effects of demographic characteristics.

Keywords: Life satisfaction, self-esteem, demographic characteristics, Agri Ibrahim Cecen University.

\section{Giriş}

Benlik, ergenlik ve gençlik döneminde yükselen ve hayat boyu devam eden dinamik bir süreç olarak kabul edilmektedir. Üniversite, gençlerin yetişkinliğe ve mesleki yaşama hazırlanma sürecinde önemli bir dönemeçtir. Üniversite dönemi de benlik saygısının en belirgin olduğu dönemlerden biridir çünkü bu yaşlarda çok sayıda biyolojik, psikolojik, sosyal ve bilişsel değişime bağlı olarak benlik saygısı bağlamında farklı ve değişken bir süreç yaşanmakta (Proctor, Linley ve Maltby, 2009) ve kişiler kariyer planlaması yapmaktadır. Benlik saygısı bireyin kendisinin kişisel bir görüşü olup, başkalarıyla olan ilişkileri, deneyimleri ve yaşamdaki başarıları ile şekillenmektedir. Benlik saygısı kişinin kendisini olduğundan üstün görmesi veya daha aşağı görmesi değil, şu anki durumu değerlendirme ve memnun olma halidir. Bu nedenle benlik saygısı kalıcı değildir, dolayısıyla anlık olarak değişebilmektedir. Rosenberg (1965)'e göre benlik saygısı bireyin kendisine yönelik olumlu veya olumsuz bir yönelimine atıfta bulunmaktadır. Bireyin kendisini yeterli, değerli ve önemli olarak değerlendirmesidir (Coopersmith, 1967). Kişi kendisini olduğu gibi, göründüğü gibi kabullenmeyi, kendisine olan güveni ve saygıyı açılayan olumlu bir ruh halidir (Yörükoğlu, 2004). Bireyin kendi öznel algılaması olduğundan bu duygusal bir değerlendirmedir. Bu durumda kişi kendinde hatalar bulabilir, yanlışlarını fark edebilir buna rağmen kendini beğenilir, sevilebilir, saygı duyulabilir, değer verilebilir biri olarak bulabilmekte ve kabul etmektedir. Birey, ulaşılabilir hedefler belirleyerek ve hedeflerini başarılı bir şekilde gerçekleştirerek benlik algısında bir artış sağlayabilmektedir. Benlik saygısının yüksek veya düşük olması, bireyin okuldaki başarısı ve becerisini, stresle mücadele etkinliğini, arkadaşlık ilişkilerinin gelişim, kalite ve canlılığını olumlu-olumsuz bir şekilde etkilemektedir. Benlik saygısının yüksek olması kişinin tutarlı ve sağlıklı bir yaşam sürdürmesine ve kendisine güvenen bir kişiliğin oluşmasına katkı sağlamaktadır (Yörükoğlu, 2004).

Benlik saygısını olumlu veya olumsuz etkileyen demografik özellikler (ör. yaş, cinsiyet, sosyoekonomik statï) farklı araştırmalarda incelenmiştir. Yapılan çalışmalarda benlik saygısı ile demografik özelikler arasında çelişkili sonuçlar bulunmuştur. Derdikman-Eiron ve arkadaşları (2011) ile Özdayı (2019)'nın yaptıkları araştırmalarda erkeklerin kadınlardan daha yüksek benlik saygısını rapor ettikleri bulunmuştur. Buna rağmen, Demirli ve Aydıner (2017) ise kadınların erkeklere oranla daha yüksek benlik saygısı puanını rapor etiklerini saptamışlardır. Ayrıca üniversite öğrencileri üzerinde yapılan çalışmada ögrencilerin okudukları branşlar ile benlik saygısı arasında anlamlı bir ilişki bulunmazken öğrencilerin okudukları sınıf ile benlik saygısı arasında anlamlı ilişki bulunmuştur (Özdayı, 2019). İkinci sınıfta okuyan öğrencilerin dördüncü sınıfta okuyan öğrencilere göre benlik saygılarının daha yüksek olduğu belirlenmiştir.

Kişisel iyi oluş genel olarak bireyin yaşamının bilişsel ve duyuşsal değerlendirmesi olarak karakterize edilmektedir (Diener, Lucas ve Oshi, 2002). Bu durumda, kişisel iyi oluş, duyuşsal ve bilişsel boyut olmak üzere iki temel bileşenden oluşmaktadır. Duyuşsal bileşen bireylerin günlük yaşamlarındaki ruh hallerini ve olumlu-olumsuz duyguların (ör. mutlu, üzgün veya yorgun) var olup olmaması anlamına gelirken (Barsade ve Gibson, 2007), yaşamdan duyulan memnuniyet bireyin kişisel iyi oluşunun bilişsel boyutunu oluşturmaktadır. Yaşam memnuniyeti kişinin genel olarak hayatının ne kadar iyi gittiğinin değerlendirmesini temsil etmektedir. Kapsayıcı ve genel bir kriteri veya insan deneyiminin nihai sonucunu simgelemekte ve kişinin yaşamı ile ilgili duygu ve tutumlarının negatiften pozitife değişen genel bir değerlendirmesini içermektedir. Dolayısıyla, yaşam memnuniyetinin değerlendirilmesi, bireyin kendi seçtiği standartlara göre, bireyin yaşamının genel kalitesinin bilişsel bir muhasebesine dayanmaktadır (Pavot ve Diener, 1993). Kişisel iyi oluşu yükssek olan bireyler yaşamdan daha yüksek düzeyde memnuniyet ve daha olumlu etkiler alırken daha düşük düzeyde olanlar için olumsuz etkiler bildirilmektedir (Diener, 1984). Yaşam memnuniyeti ve demografik özellikler arasındaki ilişkiyi inceleyen çalışmalarda yetişkinlerin benzer yaşam memnuniyeti puan ortalamaları rapor ettikleri ortaya çıkmaktadır. Dahası demografik özelliklerin ergenler açısından yaşam memnuniyeti üzerinde çok az bir etkisinin olduğunu göstermektedir (Proctor, Linley ve Maltby, 2009). Patel ve arkadaşlarının (2018) yaptıkları çalışma kadınların erkeklere oranla daha yüksek yaşam memnuniyeti puan ortalamalarına sahip 
olduklarını ortaya koyarken, Moksnes ve Espnes (2013) erkeklerin kadınlara oranla daha yüksek puan ortalaması rapor ettiklerini bulmuşlardır. Dilmaç ve Ekşi (2008) meslek yüksekokulları öğrencileri üzerinde yaptıkları araştırmada sosyoekonomik statünün yaşam memnuniyetin anlamlı bir şekilde açıladığını sosyoekonomik statüsü yüksek olan bireylerin yaşamlarından daha memnun olduklarını saptamışlardır.

Benlik saygısı üzerine yapılan çalışmalar yaşam memnuniyeti ile benlik saygısı arasında güçlü pozitif bir ilişkinin olduğunu göstermektedir (Doğan ve Eryılmaz, 2013; Patel ve diğerleri, 2018; Sowislo ve Orth, 2013). Bu ilişkinin yönü benlik saygısının daha çok yaşam memnuniyetini açıklayan bir değişken olduğudur. Myers ve Diener (1995)'e göre bireyin benlik saygısı ile yaşam memnuniyeti arasında doğrudan bir ilişki vardır, benlik saygısı yüksek bireylerin yaşamlarında daha doyumlu ve mutlu kişilerdir.

Yukarıdaki ilgili literatür incelendiğinde benlik saygısı ve yaşam memnuniyetinin birbirinden farklı birçok değişkenden etkilendiği görülmektedir. Üniversite öğrencilerinin benlik saygısı ve yaşam memnuniyeti ile ilişkili olacağı düşünülen yaş, cinsiyet, sınıf düzeyi, burs/kredi alma durumu vb. değişkenlerin incelendiği çalışmalar azdır. Bu çalışmanın amacı Ağrı İbrahim Çeçen Üniversitesi öğrencilerinin demografik özelliklerinin benlik saygısı ve yaşam memnuniyeti üzerinde anlamlı bir farklılık yaratıp yaratmadığı ve benlik saygısının yaşam memnuniyeti üzerindeki etkisini incelemektir. $\mathrm{Bu}$ amaçla aşağıdaki hipotezler geliştirilmiştir:

1. Demografik özellikler (ör. yaş, cinsiyet, sınıf düzeyi) yaşam memnuniyeti ile ilişkilidir.

2. Demografik özellikler (ör. yaş, cinsiyet, burs/kredi alıp almaması) ile benlik saygısı arasında anlamlı bir ilişki vardır.

3. Benlik saygısı ile yaşam memnuniyeti arasında anlamlı pozitif ilişki vardır.

4. Benlik saygısı, yaşam memnuniyetini demografik özellikleri kontrol edildikten sonra anlamlı bir şekilde yordar.

\section{Araştırmanın Yöntemi}

Ağrı İbrahim Çeçen Üniversitesi'nde (AİÇÜ) eğitim alan öğrencilere anket uygulanmıştır. Veri toplama işlemi yapılandırılmış bir anketin doldurulmasını içermektedir. Uygulamanın başında tüm katılımcılara katılımın gönüllü olduğu ve yanıtların anonim kalacağı konusunda yazılı bilgi verilmiştir. Anketin giriş bölümünde araştırmanın amacı, kimlik belirleyici bilgilerin istenmeyeceği, katılımcıların hakları ve yönergeleri içeren katılım sözleşmesi katılımcılara okunmuş ve onay veren katılımcılarla araştırma yüz yüze gerçekleştirilmiştir. Araştırmada öğrencilerin benlik saygısı ve yaşam memnuniyetine etki edebileceği düşünülen demografik özelliklerden; yaş, cinsiyet, bölüm, sınıf düzeyi ve burs/kredi alma durumuna göre incelenmiştir.

\section{Katılimcilar}

Bu çalışmanın verileri AİÇÜ’nde eğitim gören toplam 136 öğrenciden elde edilmiştir. Araştırmaya katılanların 79'u $(\% 58,1)$ erkek, 57'si $(\% 41,9)$ kadınlardan oluşmaktadır. Katılımcıların yaşları 18 ila 27 arasında değişirken, ortalama yaş 21,38 ve standart sapma ise \pm 1.96 'dır. Katılımcıların tamamı aktif öğrenci ve 26 farklı bölümde eğitim almaktayken 54'ü (\%39,7) birinci sınıf, 30’u (\%22,1) ikinci sınıf, 30’u (\%22,1) üçüncü sınıf ve geri kalanı $(\% 16,2)$ ise dördüncü sınıfta eğitim almaktadır. Yine katılımcıların \%67,6'sı devlet veya özel burs/kredi alırken, \%32,4’ü herhangi bir kurumdan burs/kredi almamaktadır.

\section{Veri Toplama Araçları}

$\mathrm{Bu}$ çalışmada katılımcıların yaşam memnuniyeti ve benlik saygısı durumlarını etkileyen cinsiyet, yaş, sınıf düzeyi ve burs/kredi alıp almama gibi demografik özellikler çalışmaya dahil edilmiştir.

Bireylerin yaşamlarından aldıkları doyumu belirlemek için Diener, Emmons, Larsen ve Griffin (1985) tarafından geliştirilen ve Türkçe geçerlik güvenirliği Dağlı ve Baysal (2016) tarafından yapılan "Yaşam Memnuniyeti Ölçeği” kullanılmıştır. Toplam 5 olmak üzere "Hayatımı yeniden yaşayabilseydim, hiçbir şeyi değiştirmezdim" ve "Genel olarak hayatımdan memnunum" gibi maddelerden oluşan kişinin genel yaşam 
memnuniyetini ölçen tek boyutlu bir ölçektir. Ölçek " $1=$ Kesinlikle Katılmıyorum" ile " $5=$ Kesinlikle Katılıyorum" arasında değişen 5 puanlı Likert tipi bir yapıda kullanılmıştır. Bu araştırmada yaşam memnuniyetindeki yüksek puan yaşamdan alınan doyumun yüksek olduğunu göstermektedir. Çalışmada Yaşam Memnuniyet Ölçeği'nin iç tutarlık katsayısı Cronbach's $\alpha$ ile ölçülmüş ve 0,78 bulunmuştur.

Bireylerin benlik saygısı düzeylerini belirlemek için Rosenberg (1965) tarafından geliştirilen ve Türkçe geçerlik güvenirliği Çuhadaroğlu (1986) tarafindan yapılan Rosenberg Benlik Saygısı Ölçeği kullanılmıştır. Toplam 10 maddeden oluşan ölçeğin beş maddesi "Kendimi en az diğer insanlar kadar değerli buluyorum" gibi olumlu ifadelerden oluşurken diğer 5 maddesi ise "Genelde kendimi başarısız bir kişi olarak görme eğilimindeyim" gibi olumsuz ifadelerden oluşmaktadır. Ölçek " $1=$ Kesinlikle Katılmıyorum" ile "5=Kesinlikle Katılıyorum" arasında değişen 5 puanlı Likert tipi bir yapıda kullanılmıştır. Bu ölçekten alınan toplam puanın yüksek olması bireyin benlik saygısı düzeyinin yüksek olduğunu göstermektedir. Çalışmada ölçeğin iç tutarlık katsayısı Cronbach's $\alpha$ ile ölçülmüş ve 0,74 olarak bulunmuştur.

\section{Veri Analizi}

Bütün değişkenler SPSS 22 programı ile analiz edilmiştir. Ayrıca kullanılan ölçeklerin iç geçerlik katsayıları Cronbach's alpha ile hesaplanmıştır. Değişkenlerin sıklık dağılımları, ortalama ve standart sapmalarının betimsel istatistikleri hesaplanmıştır. Benlik saygısı, yaşam memnuniyeti ve demografik özellikler arasındaki ilişkiyi ortaya koymak için Pearson Korelasyon Analizi kullanılmıştır. Benlik algısının yaşam memnuniyeti üzerindeki yordayıcı rolünü belirlemek için demografik özellikler kontrol edilerek hiyerarşik çoklu regresyon analizi hesaplanmıştır.

\section{Bulgular}

Katılımcıların demografik özellikleri Tablo 1'de gösterilmiştir. Frekans dağılımına göre katılımcıların \%58,1'inin erkek, \%41,9'unun kadın olduğu görülmektedir. Katılımcıların eğitim aldı̆̆ s sınıf düzeyi değişkenine bakıldığında \%39,7'sinin 1. sinıfta okuduğu, \%22'şerle 2. ve 3. sinıfta ve geriye kalan $\% 16,3$ 'ünün de 4. sınıfta okuduğu görülmektedir. Katılımcıların 26 farklı bölümde okuduğu, \%23,5'inin Eğitim Fakültesi, \%21,3'ünün Fen Edebiyat Fakültesi'nde olmak üzere toplamda 7 farklı fakülte/birimde eğitim aldığı belirlenmiştir. Katılımcıların \%67,6'sı devletten veya başka bir kurumdan burs/kredi aldığ saptanmıştır.

Tablo 1. Katılımcıların Demografik Özellikleri

\begin{tabular}{llcc}
\hline \multicolumn{2}{l}{ Demografik Değişkenler } & Frekans (n=136) & Yüzde (\%) \\
\hline \multirow{2}{*}{ Cinsiyet } & Kadın & 57 & 41,9 \\
& Erkek & 79 & 58,1 \\
\hline \multirow{3}{*}{ Sınıf } & 1. Sınıf & 54 & 39,7 \\
& 2. Sınıf & 30 & 22 \\
& 3. Sınıf & 30 & 22 \\
& 4. Sınıf & 22 & 16,3 \\
\hline \multirow{6}{*}{ Birim/Fakülte } & Besyo & 17 & 12,5 \\
& MYO & 17 & 12,5 \\
& Fen-Edebiyat & 29 & 21,3 \\
& Eğitim & 15 & 11 \\
& İslami İlimler & 33 & 23,5 \\
& İktisat/İdari Bilimler & 13 & 9,6 \\
\multirow{2}{*}{ Burs/Kredi } & Alıyor & 13 & 9,6 \\
\hline & Almıyor & 92 & 67,6 \\
\hline
\end{tabular}


Yaşam memnuniyeti ve benlik saygısının betimleyici istatistikleri Tablo 2'de gösterilmiştir. Katılımcılar, yaşam memnuniyeti (ortalama $=16,84$ ) ve benlik saygısı (ortalama $=35,90$ ) ölçeklerinde görece yüksek puanlar rapor etmişlerdir. Araştırmada kullanılan ölçeklerin skewness (çarpıklık) ve kurtosis (basıklık) istatistiki değerlerinin çok iyi düzeyler arasında olduğu ve verilerin normal dağılım gösterdiğini ortaya koymaktadır.

Tablo 2. Çalışmada Kullanılan Ölçekler İçin Betimleyici İstatistikler

\begin{tabular}{lcccccccc}
\hline & \multirow{2}{*}{ Min. } & \multirow{2}{*}{ Mak. } & \multirow{2}{*}{ Ort. } & \multirow{2}{*}{ S.S } & \multicolumn{2}{c}{ Skewness (Çarpıklık) } & \multicolumn{2}{c}{ Kurtosis (Basıklı) } \\
\cline { 7 - 10 } & & & & & İstatistik & S.H.O & İstatistik & S.H.O \\
\hline Yaşam memnuniyeti & 7 & 25 & 16,84 & 3,84 & $-0,02$ & 0,21 & -0.76 & 0,41 \\
Benlik saygıs1 & 19 & 50 & 35,90 & 7,03 & 0,29 & 0,21 & $-0,42$ & 0,41 \\
\hline
\end{tabular}

Pearson Product-Moment korelasyonuyla; demografik özellikler, benlik saygısı ve yaşam memnuniyeti hesaplanmış ve Tablo 3'te gösterilmiştir. Korelasyon analizine göre katılımcıların yaş1; cinsiyet, okudukları sınıf düzeyi ve burs/kredi alıp almama ile anlamlı bir ilişkiye sahiptir. Erkekler, kadın katılımcılara göre daha büyük yaşlardadır. Yine yaş artarken katılımcıların üst sınıflarda olma olasılıkları artarken katılımcıların burs/kredi alma olasılığı düşmektedir. Katılımcıların burs/kredi almaları ile benlik saygısı arasında anlamlı pozitif bir korelasyon bulunmuştur. Buna göre burs/kredi alan katılımcılar, benlik saygısı puanlarını daha yüksek rapor etmişlerdir. Katılımcıların benlik saygısı ile yaşam memnuniyetleri arasında anlamlı ve güçlü bir pozitif ilişki bulunmaktadır. Buna göre benlik saygısı ile yaşam memnuniyeti arasında doğru orantı sözkonusudur.

Tablo 3. Değişkenler Arası Korelasyon Analizi

\begin{tabular}{lcccccc}
\hline Değişkenler & 1 & 2 & 3 & 4 & 5 & 6 \\
\hline 1. Yaş & 1 & & & & & \\
2. Cinsiyet &, $28^{* *}$ & 1 & & & & \\
3. Sinıf &, $48^{* *}$ &, 02 & 1 & & & \\
4. Burs/Kredi &,$- 34^{* *}$ &, 01 &,- 12 & 1 & & \\
5. Benlik saygis1 &,- 03 &, 07 &,- 04 &, $20^{*}$ & 1 & \\
6. Yaşam memnuniyeti &,- 04 &,- 03 &,- 05 &,- 01 &, $47^{* *}$ & 1 \\
\hline$* * . p<.01 ; * . p<.05$ & & & & & & \\
\hline
\end{tabular}

Katılımcıların cinsiyetlerinin benlik saygısı ve yaşam memnuniyeti üzerinde anlamlı bir farklılık oluşturup oluşturmadığını test etmek için birbirinden bağımsız örneklem t-testi uygulanmış ve analiz sonuçları Tablo 4'te gösterilmiş̧tir. Katılımcıların cinsiyetleri için benlik saygısı puanlarını karşılaştırmak amacıyla bağımsız örneklem t-testi hesaplanmıştır. Analiz sonuçlarına göre erkek öğrenciler $(\mathrm{M}=36,16$, $\mathrm{SD}=6,97)$ ile kadın öğrenciler $(\mathrm{M}=35,54, \mathrm{SD}=7,15 ; \mathrm{t}(134)=0,507, \mathrm{p}>0,05)$ arasında benlik saygıs1 puan ortalamalarının birbirinden anlamlı bir şekilde farklılık göstermediği ortaya çıkmaktadır. Ortalamalardaki farklılıkların büyüklüğü (Ort. fark =0,62; \%95 Güven Aralığı: -1.80 ila 3,04) çok küçük olarak (eta kare $=.002$ ) elde edilmiştir. Cinsiyet için yaşam memnuniyeti puanlarını karşılaştırmak amacıyla yine bağımsız örneklem t-testi hesaplanmıştır. Ayrıca, t-testi analizine göre erkekler $(\mathrm{M}=16,47, \mathrm{SD}=3,80)$ ile kadınlar $(\mathrm{M}=17,35, \mathrm{SD}=3,86 ; \mathrm{t}(134)=-1,329, \mathrm{p}>0,05)$ arasında yaşam memnuniyeti puan ortalamalarında da anlamlı bir fark bulunamamıştır. Yaşam memnuniyeti ortalamalardaki farklılıkların büyüklüğ̈̈ (Ort. fark $=-0,88$; \%95 Güven Aralığ1: -2.20 ila 0,43 ) orta büyüklükte olarak (eta kare $=, 013$ ) elde edilmiştir. 
Tablo 4. Benlik Saygısı ve Yaşam Memnuniyetinin Cinsiyet Açısından Karşılaştırılması Bağımsız Örneklem t-Testi

\begin{tabular}{lllccccc}
\hline Boyutlar & Cinsiyet & $\mathrm{N}$ & Ortalama & Standart S. & Ort. S. Hatas1 & $t$ & $p$ \\
\hline Benlik & Kadın & 57 & 35,54 & 7,15 & 0,95 & \multirow{2}{*}{0,51} & \multirow{2}{*}{0,61} \\
Saygis1 & Erkek & 79 & 36,16 & 6,97 & 0,78 & & \\
Yaşam & Kadın & 57 & 17,35 & 3,86 & 0,51 & $-1,33$ & 0,19 \\
Memnuniyeti & Erkek & 79 & 16,47 & 3,80 & 0,43 & & \\
\hline
\end{tabular}

Katılımcıların eğitim aldıkları sınıf düzeyine göre benlik saygısı ve yaşam memnuniyeti açısından bir farklılık oluşturup oluşturmadığını test etmek için her bir bağımsız değişken için gruplar arası tek yönlü varyans analizi (ANOVA) hesaplanmış ve analiz sonuçları Tablo 5'te gösterilmiştir. Analiz öncesinde testin varsayımları kontrol edilmiş ve değerler analiz için uygun bulunmuştur. Buna göre öğrencilerin eğitim aldıkları sınıf düzeyi ile benlik saygısı arasında anlamlı bir ilişki bulunamamıştır $[\mathrm{F}(3,132)=0,25, \mathrm{p}>$ $0,05]$. Benzer analiz yaşam memnuniyeti için de hesaplanmış ve eğitim alınan sınıf düzeyi ile yaşam memnuniyeti arasında anlamlı bir ilişki bulunamamıştır $[\mathrm{F}(3,132)=0,31, \mathrm{p}>0,05]$.

Tablo 5. Katılımcıların Benlik Saygısı ve Yaşam Memnuniyetinin Okudukları Sınıf Düzeylerine göre Farklılaşıp Farklılaşmadığına ilişkin ANOVA Sonuçları

\begin{tabular}{lllcccc}
\hline \multicolumn{1}{c}{ Boyut } & Sinıf Düzeyi & N & Ortalama & SS & $F$ & $p$ \\
\hline \multirow{4}{*}{ Benlik } & 1. Sinıf & 54 & 36,29 & 7,56 & & \\
Saygis1 & 2. Sinif & 30 & 35,37 & 7,57 & 0,25 & 0,86 \\
& 3. Sinif & 30 & 36,36 & 6,56 & & \\
& 4. Sinif & 22 & 35,07 & 5,72 & & \\
\multirow{3}{*}{ Yaşam } & 1. Sinif & 54 & 16,91 & 4,05 & & \\
Memnuniyeti & 2. Sinif & 30 & 17,30 & 3,81 & \multirow{2}{*}{0,31} & 0,82 \\
& 3. Sinif & 30 & 16,39 & 3,87 & & \\
& 4. Sinif & 22 & 16,63 & 3,44 & & \\
\hline
\end{tabular}

Analiz yapılmadan önce ilgili hiyerarşik regresyon analizi için varsayımlar test edilmiştir. Çoklu hiyerarşik regresyon analizi için gereken minimum örneklem büyüklügünü belirlemek için G*Power (Erdfelder, Faul veBuchner, 1996) kullanılmıştır. Modeldeki muhtemel yordayıcı değişken sayısı 5, beklenilen etki değeri ( $\mathrm{f} 2=0.15$ ) ve $\mathrm{p}<0,05$ düzeyinde istenilen istatiksel güven aralığ 0,95 'tir. Bu analiz için gerekli örneklem boyutu $\mathrm{n}=89$ olarak hesaplamış fakat bu çalışma için veri toplanan örneklem $\mathrm{n}=$ 136'dir ve minimum örneklemin oldukça üzerindedir. Yordayan değişkenler arasında çoklu-doğrusalllık açısından her bir değişken için varyans büyütme (enflasyon) faktörü (VIF) ve tolerans sırasıyla 2,76'dan büyük ve 0,36 'dan küçük olmadığı belirlenmiştir. Bu nedenle VIF eşik değerinin en az 5 ve tolerans istatistiklerinin 0,2'den küçük olduğu varsayımını ihlal etmemektedir (Cheung \& Rensvold, 2002). Yukarıda gösterildiği gibi analizi etkileyecek herhangi temel bir normallik sorunu gözlenmemiştir.

Benlik saygısının yaşam memnuniyeti üzerindeki etkisini açıklamak değerlendirmek için çoklu regresyon analizi hesaplanmıştır. Araştırmada katılımcıların yaşam memnuniyetini yordayan çoklu regresyon analizinin sonuçları Tablo 6'da verilmiştir. 
Tablo 6. Yaşam Memnuniyetini Açıklayan Değişkenlerin Hiyerarşik Çoklu Regresyon Analizi

\begin{tabular}{|c|c|c|c|c|}
\hline & \multicolumn{4}{|c|}{ Yaşam Memnuniyeti } \\
\hline Değişkenler & B & Beta & $t$ & $p$ \\
\hline Model 1 & \multicolumn{4}{|c|}{$\begin{array}{c}F(4,131)=, 491, r=, 12 \\
r^{2}=, 015, p>0,05\end{array}$} \\
\hline Cinsiyet & 0,92 & 0,12 & 1,26 & 0,21 \\
\hline Yaş & 0,05 & 0,02 & 0,21 & 0,83 \\
\hline Sinif & $-0,16$ & $-0,05$ & $-0,48$ & 0,63 \\
\hline Burs/kredi & 0,03 & 0,00 & 0,04 & 0,97 \\
\hline Model 2 & \multicolumn{4}{|c|}{$\begin{array}{c}F(5,130)=8,489, r=, 50 \\
r^{2}=, 246, p<0,01\end{array}$} \\
\hline Cinsiyet & 1,04 & 0,13 & 1,61 & 0,11 \\
\hline Yaş & $-0,00$ & $-0,00$ & $-0,02$ & 0,98 \\
\hline Sinif & $-0,09$ & $-0,03$ & $-0,30$ & 0,77 \\
\hline Burs/kredi & 0,87 & 0,11 & 1,27 & 0,21 \\
\hline Benlik sayg1sı & 0,27 & 0,49 & 6,32 & $\mathbf{0 , 0 0}$ \\
\hline
\end{tabular}

İki modelli çoklu regresyon için cinsiyet, yaş, sınıf ve benlik saygısı bağımsız değişken iken, yaşam memnuniyeti araştırmanın tek bağımlı değişkenidir. Birinci modelde demografik özellikler hesaplanırken model 2'de benlik saygısı hesaplanmıştır. Çoklu regresyon analiz sonucu r2'nin birinci model için sıfırdan farklı olduğu fakat anlamlı olmadığ $\mathrm{F}(4,131)=, 491 ; \mathrm{p}>0,05$ ortaya koymaktadır. Bu sonuca göre demografik özelliklerin yaşam memnuniyeti açıklamada anlamlı bir etkisinin olmadığı görülmektedir. Benlik saygısı bağımsız değişkeni analize dâhil edildikten sonra model bir bütün olarak $\mathrm{F}(5,130)=8,489$; $\mathrm{p}<0,01$ 'de anlamlı bir farklılık göstererek katılımcıların yaşam memnuniyetinin varyansının yüzde 25'ini açıklamaktadır. Dolayısıyla benlik saygısı modeli tek başına modeli yordamaktadır.

\section{Sonuç ve Tartışma}

Bu çalışmada AİÇÜ öğrencilerinin demografik özelliklerinin benlik saygısı ile ilişkisi ve demografik özellikler ile benlik saygısı birlikte yaşam memnuniyeti üzerindeki etkisi incelenmiştir. Araştırmanın sonuçlarına göre demografik özelliklerden cinsiyet, yaş, sınıf düzeyi ve burs/kredi gibi değişkenlerin yaşam memnuniyeti puan ortalaması üzerinde anlamlı bir etkiye sahip olmadığ1 saptanmıştır. Buna göre katılımcıların yaşı, kadın veya erkek olması, sınıf düzeyleri, bünyesinde eğitim aldıkları fakülte/birimler ve burs/kredi alıp almaması ile yaşam memnuniyeti arasında anlamlı bir fark bulunmamıştır. Bu açıdan yapılan çalışmanın sonuçları demografik özellikler ile yaşam memnuniyeti arasındaki ilişki bakımından birçok çalışmayı destekler nitelikteyken (Kabasakal \& Baş, 2013; Moksnes \& Espnes, 2013), bazı çalışmalarla da paralellik göstermemiştir (Patel, vd., 2018). Dolayısıyla demografik özellikler yaşam memnuniyeti ile ilişkilidir şeklindeki hipotezimiz reddedilmiştir. Böyle bir sonucun ortaya çıkmasının çeşitli sebepleri olabilmektedir. Bu sebeplerden birincisi katılımcıların benzer sosyoekonomik çevreden gelmiş olması ve birbirine yakın yaş gruplarında olmasıdır. Diğer bir sebep ise katılımcıların görece az olmasından kaynaklı olarak demografik özelliklerin yaşam memnuniyeti üzerinde anlamlı bir farklılık yaratmasını engellediği söylenebilir. En azından öğrencilerin eğitim aldıkları sınıf düzeyinin yaşam memnuniyeti ile anlamlı bir ilişki içerisinde olması beklenmekteydi çünkü öğrencilerin gelecek kaygısı ve mezun olduktan sonra iş bulamama kaygısı okudukları sınıf düzeyi artıkça yükseldiği tahmin edilmekteydi (Tekin Tayfun ve Korkmaz, 2016). Bu öngörüye rağmen eğitim alınan sınıf düzeyi ile yaşam memnuniyeti arasında herhangi bir ilişki saptanmamıştır.

Araştırmanın demografik özelliklerin benlik saygısı ile ilişkisi olduğuna dair olan ikinci hipotezi ise kısmi olarak kabul edilmiştir. Çünkü yalnızca öğrencilerin burs/kredi alması benlik saygısı ile pozitif bir ilişki içerisindedir. Buna göre öğrencilerin burs/kredi alması onların benlik saygısı puan ortalamalarını artırmaktadır. Fakat katılımcıların kadın veya erkek olması, eğitim aldıkları sınıf düzeyi ile yaş değişkenin 
benlik saygısı üzerinde herhangi bir ilişkisi belirlenmemiştir. Katılımcı öğrencilerin burs/kredi alıp almamalarına göre benlik saygısı düzeylerine bakıldığında burs/kredi almak ile benlik saygısı arasında pozitif bir ilişki olduğu tespit edilmiştir. Buna göre öğrencilerin burs/kredi alması benlik saygısı puan ortalamaları üzerinde anlamlı bir etkiye sahiptir. Bu durumda hipotez 2'nin bir bölümü kabul edilmiştir. Öğrencilerin maddi bir destek alması kendilerine güvenmelerine ve benlik saygılarının artmasına yardımcı olduğu düşünülebilir.

Değişkenler arası korelasyon analizi sonuçlarına göre benlik saygısı ile yaşam memnuniyeti arasında pozitif bir ilişki söz konusudur. Katılımcıların benlik saygılarının yüksek olması yaşam memnuniyetleriyle doğrudan ilişkilidir. Bu sonuçlar önceki araştırmalarla benzerlik göstermektedir (Yıldırım, Alshehri ve Aziz, 2019). Regresyon analizinde de görüldüğü üzere demografik özellikler kontrol edildikten sonra benlik saygısı katılımcıların yaşam memnuniyetlerinin \%25'ini açıklamaktadır. Buna göre benlik saygısının yaşam memnuniyetinin güçlü bir açıklayıcısı olduğunu sonucu ortaya çıkmaktadır (Proctor, Linley ve Maltby, 2009). Dolayısıyla araştırmanın üçüncü hipotezi kabul edilmektedir. Yaşam memnuniyetini etkileyen faktörlerin belirlenmesinin önemi göz önünde bulundurulduğunda (Yıldırım, 2019; Yıldırım ve Alanazi, 2018), bu çalışmanın sonuçları literatüre ve gelecekte yapılacak olan araştırmalar için önem arz etmektedir. Sonuç olarak, bu çalışmada elde edilen bulgular öğrencilerin benlik saygısının yaşam memnuniyeti ile ilişkili önemli bir değişken anlayışını desteklemektedir. Coleman ve Hendry’ye (1990) göre yüksek benlik saygısına sahip insanların düşük benlik saygısına sahip olanlara oranla daha mutlu, daha sağlıklı oldukları ve daha fazla üretkenlik gösterdiklerini, zorlukların üstesinden gelmek için daha fazla çabaladıklarını ve başkalarını kabul etmede ve akranlarının baskılarına boyun eğmede daha az eğilim gösterdiklerini belirlemişlerdir. Dolayısıyla kişinin benlik saygısının yüksek olması yaşam memnuniyeti açısından pozitif bir etki sağlamaktadır.

Bu çalışmada nedensellik ve örnekleme yöntemiyle ilgili bazı metodolojik sınırlılıklar gibi dikkate alınması gereken bazı kısıtlamalar vardır. İlk olarak, tüm çalışma değişkenleri, benlik saygısı, yaşam memnuniyeti ve demografik bilgiler, değişkenler arasındaki korelasyonu şişirme veya deflasyon potansiyeline sahip olabilen öz bildirim anketi kullanılarak ölçülmüştür. İkincisi, bu çalışmada, benlik saygısı ve yaşam memnuniyeti arasında nedensel bir ilişki kurmanın imkansız olduğu kesitsel bir tasarım kullanılmıştır. Daha açık ifadeyle benlik saygısı ile yaşam memnuniyeti arasındaki ilişkinin yönü açık değildir ve birçok nedenden dolayı bu ilişki etkilenebilir. Örneğin, benlik saygısının daha yüksek yaşam memnuniyetini veya yaşam memnuniyetinin daha yüksek benlik saygısını etkileyip etkilemeyeceği belirsizdir. Böyle bir sonuca varmak için, sonraki araştırmalar mevcut bulguları deneysel veya boyutsal tasarımlar gibi alternatif yöntemlerle destekleyebilir. Üçüncüsü de Ağrı İbrahim Çeçen Üniversitesinde okuyan öğrenciler örneklemiş olsa da mevcut bulgular farklı tüm öğrencilere ve gruplara genelleştirilemez.

Sonuç olarak, bu araştırmaya dahil olan araştırmacıların cinsiyet hariç diğer demografik özelliklerinin yaşam memnuniyeti açısından farklılık göstermediği rapor edilmiştir. Kadınlar daha yüksek yaşam memnuniyeti puan ortalamasına sahiptir. Çalışmanın bulguları, benlik saygısının yaşam memnuniyeti açısından önemli faktör olduğunu ve benlik saygısı puan ortalaması yüksek olan katılımcıların yaşamdan daha fazla doyum aldıklarını göstermektedir.

\section{Kaynakça}

Barsade, S. G. ve Gibson, D. E. (2007). Why does affect matter in organizations? The Academy of Management Perspectives, 21(1), 36-59.

Cheung, G. W. ve Rensvold, R. B. (2002). Evaluating goodness-of-fit indexes for testing measurement in variance. Structural Equation Modeling, 9(2), 233-255.

Coleman J. ve Hendry, L. (1990). The nature of adolescence. London: Routledge.

Coopersmith, S. (1967). Parental characteristics related to self-esteem. In the antecedents of self-esteem. San Francisco: Freeman.

Çuhadaroğlu, F. (1986). Adölesanlarda benlik saygısı. Yayınlanmamış Uzmanlık Tezi. Ankara: Hacettepe Üniversitesi Tıp Fakültesi, Psikiyatri Bölümü.

Dağlı, A. ve Baysal, N. (2016). Yaşam doyumu ölçeğinin Türkçe’ye uyarlanması: Geçerlik ve güvenirlik çalişması. Elektronik Sosyal Bilimler Dergisi, 15(59), 1250-1262. 
Demirli, C. ve Aydıner, S. (2017). Ortaokul öğrencilerinin bilgisayar bağımlılıkları ile benlik saygıları arasındaki ilişkinin çeşitli demografik değişkenlere göre incelenmesi. İstanbul Ticaret Üniversitesi Sosyal Bilimler Dergisi, 16(31), 47-60.

Derdikman-Eiron, R., Indredavik, M. S., Bratberg, G. H., Taraldsen, G., Bakken, I. J. ve Colton, M. (2011). Gender differences in subjective well-being, self-esteem and psychosocial functioning in adolescents' symptoms of anxiety and depression: Findings from the Nord-Trøndelag health study. Scandinavian Journal of Psychology, 52, 261-267.

Diener, E. (1984). Subjective well-being. Psychological Bulletin, 95, 542-575.

Diener, E., Emmons, R. A., Larsen, R. J. ve Griffin, S. (1985). The Satisfaction with life scale. Journal of Personality Assessment, 49(1), 71-75.

Diener, E., Lucas, R. E. ve Oishi, S. (2002). Subjective well-being: Thescience of happiness and life satisfaction. Handbook of Positive Psychology, 2, 63-73.

Dilmaç, B. ve Ekşi, H. (2008). Meslek yüksek okullarında öğrenim gören öğrencilerin yaşam doyumları ve benlik saygılarının incelenmesi. Selçuk Üniversitesi Sosyal Bilimler Enstitüsü Dergisi, (20), 279-289.

Doğan, T. ve Eryılmaz, A. (2013). İki boyutlu benlik saygısı ve öznel iyi oluş arasındaki ilişkilerin incelenmesi. Pamukkale Üniversitesi Ĕ̌itim Fakültesi Dergisi, 33(1), 107-117.

Erdfelder, E., Faul, F. ve Buchner, A. (1996). GPOWER: A general power analysis program. Behaviour Research Methods, Instruments \& Computers, 28(1), 1-11.

Kabasakal, Z. ve Baş, Aslı Uz. (2013). Öğretmen adaylarında yaşam doyumunun yordayıcısı olarak problem çözme becerileri. Ĕ̈itim ve Öğretim Araştırmaları Dergisi, 2(1), 27-35.

Moksnes, U. K. ve Espnes, G. A. (2013). Self-esteem and life satisfaction in adolescents-gender and age as potential moderators. Quality of Life Research, 22(10), 2921-2928.

Myers, D. G. ve Diener, E. (1995). Who is happy? Psychological Science, 6(1), 10-19.

Özdayı, N. (2019). Üniversite öğrencilerinin benlik saygısının bazı demografik bilgilere göre incelenmesi. Spor Ĕgitim Dergisi, $3(1), 69-80$.

Patel, A. K., Tiwari, S. K., Singh, S. ve Lindinger-Sternart, S. (2018). Self-esteemand life satisfaction among university students of Eastern Uttar Pradesh of India: A demographical perspective. Indian Journal of Positive Psychology, 9(3), 382-386.

Pavot, W. ve Diener, E. (1993). Review of the satisfaction with life scale. Psychological Assessment, 5, 164-172.

Proctor, C. L., Linley, P. A. ve Maltby, J. (2009). Youth life satisfaction: A review of the literature. Journal of Happiness Studies, $10,583-630$.

Rosenberg, M. (1965). Society and the adolescent self-image. Princeton, NJ: Princeton UniversityPress

Sowislo, J. F. ve Orth, U. (2013). Does low self-esteem predict depression and anxiety? A meta-analysis of longitudinal studies. Psychological Bulletin, 139(1), 213-240.

Tekin Tayfun, A. ve Korkmaz, A. (2016). Üniversite öğrencilerinde işsizlik kaygısı: Süleyman Demirel Üniversitesi öğrencileri üzerinde bir araştırma. Mehmet Akif Ersoy Üniversitesi Sosyal Bilimler Enstitüsü Dergisi, 8(17), 534-558.

Yildırım, M. (2019). Mediating role of resilience in the relationships between fear of happiness and affect balance, satisfaction with life, and flourishing. Europe's Journal of Psychology, 15(2), 183-198.

Yıldırım, M. veAlanazi, Z. S. (2018). Gratitude and life satisfaction: Mediating role of perceivedstress. International Journal of Psychological Studies, 10(3), 21-28.

Yıldırım, M., Alshehri, N. A. ve Aziz, I. A. (2019). Does self-esteem mediate the relationship between gratitude and subjective well-being? Polish Psychological Bulletin, 50(2), 149-156.

Yörükoğlu, A. (2004). Gençlik çağı, ruh sağlığı ve ruhsal sorunlar. İstanbul: Özgür Yayınları. 